\title{
The effect of duloxetine on ECoG activity of absence-epilepsy model in WAG/Rij rats
}

\section{Absans epilepsi modeli olan WAG/Rij sıçanlarda duloksetinin ECoG aktivitesi üzerine etkisi}

\author{
(1) Hatice Aygün \\ Department of Physiology, Tokat Gaziosmanpasa University Faculty of Medicine, Tokat, Turkey
}

\begin{abstract}
Introduction: Many epidemiological studies have found a high incidence of depression and anxiety in people with epilepsy. Duloxetine is a selective inhibitor of serotonin and norepinephrine reuptake (SNRI) and commonly prescribed in a patient with major depressive disorder. The aim of this study was to investigate the effect of duloxetine on the WAG/Rij rat in an experimental rat model of absence-epilepsy.

Methods: WAG/Rij rats were randomly assigned into 5 groups with 7 animals in each group. Tripolar electrodes were placed on the skull to perform electrocorticography (ECOG) evaluation. Then, following the recovery period, ECoGs were recorded at 09:00 am for 3 hours every day. Subsequently, duloxetine $(1,5,10$ and $30 \mathrm{mg} / \mathrm{kg})$ was injected intraperitoneally (i.p). After the treatment program, ECoG recordings were taken for 3 hours. And then all animal anxiety-like behavior by using the behavioral test, open field test (OFT) was performed after duloxetine $(1,5,10$ and $30 \mathrm{mg} / \mathrm{kg})$ treatment. The total number and the total duration of the spike-wave discharges (SWDs) were calculated offline. The number of squares crossed (locomotor activity) and the duration of grooming episodes were analyzed in OFT.

Results: The doses of duloxetine $(1 \mathrm{mg} / \mathrm{kg})$ did not alter ECoG and OFT parameters. The 5,10 and $30 \mathrm{mg} / \mathrm{kg}$ doses of duloxetine decreased the total number and the total duration of SWDs, $(p<0.05)$ and increased the number of squares crossed when compared to with control group $(p<0.05)$ without changing duration of grooming episodes ( $p>0.05$ ). Intraperitoneal administering of $1 \mathrm{mg} / \mathrm{kg}$ duloxetine did not show any statistically significant change in regard to the number and duration of SWDs.
\end{abstract}

Discussion and Conclusion: In the present study, duloxetine reduce dose-dependent absences-like seizures and anxiety-like behavior.

Keywords: Absence epilepsy; duloxetine; ECoG; open field test; WAG/Rij rat.

\begin{abstract}
Özet
Amaç: Birçok epidemiyolojik çalışma epilepsili hastalarda yüksek depresyon ve anksiyete insidansı olduğunu bulmuştur. Duloxetin, serotonin ve norepinefrin geri alımının seçici bir inhibitörüdür (SNRI) ve genellikle majör depresif bozukluğu olan hastalara reçete edilir. Bu çalışmanın amacı, absans-epilepsinin deneysel bir hayvan modeli olan WAG/Rij sıçanlarda epileptiform aktive üzerine duloksetinin etkisini araştırmaktır.

Gereç ve Yöntem: WAG/Rij sıçanlar her grupta 7 hayvan bulunan 5 gruba rasgele ayrıldı. Elektrokortikografi (ECoG) değerlendirmesi yapabilmek için kafataslarına tripolar elektrotlar yerleştirildi. Daha sonra, iyileşme periyodunu takiben, her sabah saat 09:00'da üç saat bazal ECoG kayıtları alındı. Sonrasında, duloksetin (1, 5, 10 ve 30 mg/kg) intraperitoneal (i.p) enjekte edildi. Tedavi programı sonrası, ECoG kaydı 3 saat boyunca alındı. Daha sonra tüm hayvanların anksiyete benzeri davranışları davranışsal test olan açık alan testi (AAT) ile test edildi. Diken dalga deşarjlarının (DDD) toplam sayısı ve toplam süresi hesaplandı. Geçilen karelerin sayısı (lokomotor aktivite) ve grooming bölümlerinin süresi AAT'de analiz edildi.

Bulgular: Duloksetin (1 mg/kg) dozları ECoG ve AAT parametrelerini değiştirmedi. İntraperitoneal 1 mg/kg duloksetin uygulaması, DDD'lerin sayısı ve süresi açısından istatistiksel olarak anlamlı bir değişiklik göstermedi. 5, 10 ve 30 mg/kg duloksetin dozları kontrol grubuyla karşılaştııılığı zaman DDD'lerin toplam sayısını ve süresini azalttı, $(p<0.05)$ ve grooming süresini değiştirmeksizin geçilen karelerin sayısını arttırdı.

Sonuç: Sunulan çalışmada, duloksetinin, doza bağımlı olarak absans benzeri nöbetleri ve anksiyete benzeri davranışları azalttığı görüldü.

Anahtar Sözcükler: Absans epilepsi; açık alan testi; duloksetin; ECoG; WAG/Rij sıçan.
\end{abstract}


$E^{p}$ ilepsy is a complex and common neurological disorder that affects about 50 million epilepsy patients in the World, which constitutes 2-3\% of all Word population. ${ }^{[1]}$ Depression is also considered one of the most important causes of poor quality of life in people with epilepsy. ${ }^{[2]}$ Comorbid depression and anxiety disorders in a patient with epilepsy are common. Previous studies demonstrated that $11-25 \%$ suffered from anxiety and $9-37 \%$ of patient with epilepsy suffered from depression. ${ }^{[3,4]}$ A lot of studies showed that depression has been associated with an increased risk of seizures in a patient with epilepsy. ${ }^{[5]}$ Previous clinical and experimental studies suggest that seizures severity associated with the choice of antidepressant drugs and dose prescribed in a patient. ${ }^{[6,7]}$ Furthermore, older antidepressants such as imipramine, amitriptyline, and bupropion were reported to decrease the seizure threshold in a patient with epilepsy. ${ }^{[5]}$ Selective serotonin reuptake inhibitors (SSRIs) and serotonin noradrenaline reuptake inhibitors (SNRIs) are commonly the prescribed antidepressants in a patient with depression and epilepsy to treat depression, because of their less risk of seizure. ${ }^{[5]}$

Duloxetine is a potent SNRI and is used in the treatment of female stress urinary incontinence, peripheral diabetic neuropathic pain, fibromyalgia, generalized anxiety disorder and major depression. A lot studies demonstrated the proconvulsant and anticonvulsant effect of duloxetine in various experimental study. ${ }^{[6-8]}$

Rats of the Wistar Albino Glaxo/Rijswijk rats (WAG/Rij) strain display spontaneous SWDs morphologically similar to human absence seizures. ${ }^{[9]}$ Also, many experimental studies demonstrated that WAG/Rij rats exhibit depression-like behavioral symptoms. ${ }^{[10]}$

The aim of this study was to investigate the relationship between dose-like seizure and anxiety-depression in WAG/Rij rats.

\section{Materials and Method}

\section{Animals}

Six-month-old male 35 WAG/Rij rats were used in this study. All animals were under kept in controlled environmental conditions (50 $\pm 8 \%$ humidity, $21 \pm 1^{\circ} \mathrm{C}$; a 12 -hour/12-hour light/ dark cycle; lights on at 06:00-18:00 hour) and a sound attenuated room. Rats were allowed free access to food (standard laboratory chow) and water until the time of experiments. The experimental protocol was approved by the Ethical Committee of Tokat Gaziosmanpaşa University and procedures involving animals and their care was conducted in accordance with the European Union Directive 2010/63/EU.

\section{Experimental design}

WAG/Rij rats were assigned into 5 groups with 7 animals in each group randomly.

(Group 1); WAG/Rij rats received saline (4 ml/kg/i.p).

(Group 2); WAG/Rij rats received duloxetine (1 mg/kg/i.p).
(Group 3); WAG/Rij rats received duloxetine (5 mg/kg/i.p).

(Group 4); WAG/Rij rats received duloxetine (10 mg/kg/i.p).

(Group 5); WAG/Rij rats received duloxetine (30 mg/kg/i.p).

\section{Drugs and drug administration}

Ketamine hydrochloride and xylazine hydrochloride were purchased from Sigma Chemical Co and duloxetine taken from the local pharmacy. Duloxetine was dissolved in sterile physiologic saline. The doses of the drugs were determined in accordance with previous studies. ${ }^{[6,7]}$

\section{Experimental absences epilepsy model in WAG/Rij rats}

\section{Implantation of the electrode for ECoG recording}

Rats were fasted 1 day before the operation. Stereotactic surgery was performed under intraperitoneal (i.p.) ketamine and xylazine (90 and $10 \mathrm{mg} / \mathrm{kg}$, respectively) anesthesia. The membrane on the bone tissue was cleared and the detected reference point (bregma). Tripolar electrodes were placement in rat skull for ECoG recording. Tripolar electrodes were placement in the coordinates described as follows; positive electrode in the frontal cortex (AP $2 \mathrm{~mm}$; $\mathrm{L} 3.5 \mathrm{~mm}$ ), negative electrode in the parietal area (somatosensory cortex, AP- 6 mm; L 4 $\mathrm{mm}$ ) and reference electrode over the cerebellum Electrodes were permanently fixed to the skull with cold dental acrylic together with additional two stainless steel screws. ${ }^{[11,12]}$ After the surgery, animals housed in individual cages and kept alone in order to prevent damages of the electrode. All animals were allowed to recover seven days before ECoG recording (Fig. 1).

\section{Electroencephalogram recording}

After 7 days of healing, rats were habituated to the in a registration cage $(26 \times 18 \times 42 \mathrm{~cm})$ and the electrode fixed to the rat skull was connected to the recording apparatus with a cable. Basal ECoG recordings were taken for 3 hours (between 09:00 and 12:00 AM) performed using the acknowledge software (version 3.8) and the MP150 multi-channel physiological analysis system (BioPac Systems Inc.; USA) from freely moving animals in a noise-isolated room. Duloxetine was administered (i.p.) in different doses at 1, 5, 10 and $30 \mathrm{mg} / \mathrm{kg}$ rate separately and then ECoG recordings were taken for 3 hours (between 09:00 and 12:00 AM). The number, duration, and amplitude of spike-wave discharges (SWDs) in the recordings were used for evaluating the seizures (Fig. 2).

\section{Evaluation of anxiety- depression-like behaviors in WAG/Rij rats}

\section{Open field test}

After the duloxetine injection and $180 \mathrm{~min}$ ECoG recording, the beginning of the open field test. The test was performed in a white Plexiglas square field $(100 \times 100 \mathrm{~cm}$ square arena divided into 64 equal segments) with $30 \mathrm{~cm}$ high walls. Rats were habituated to the test room for seven days. The WAG/ Rij rat was initially put in the center of the open field and its 

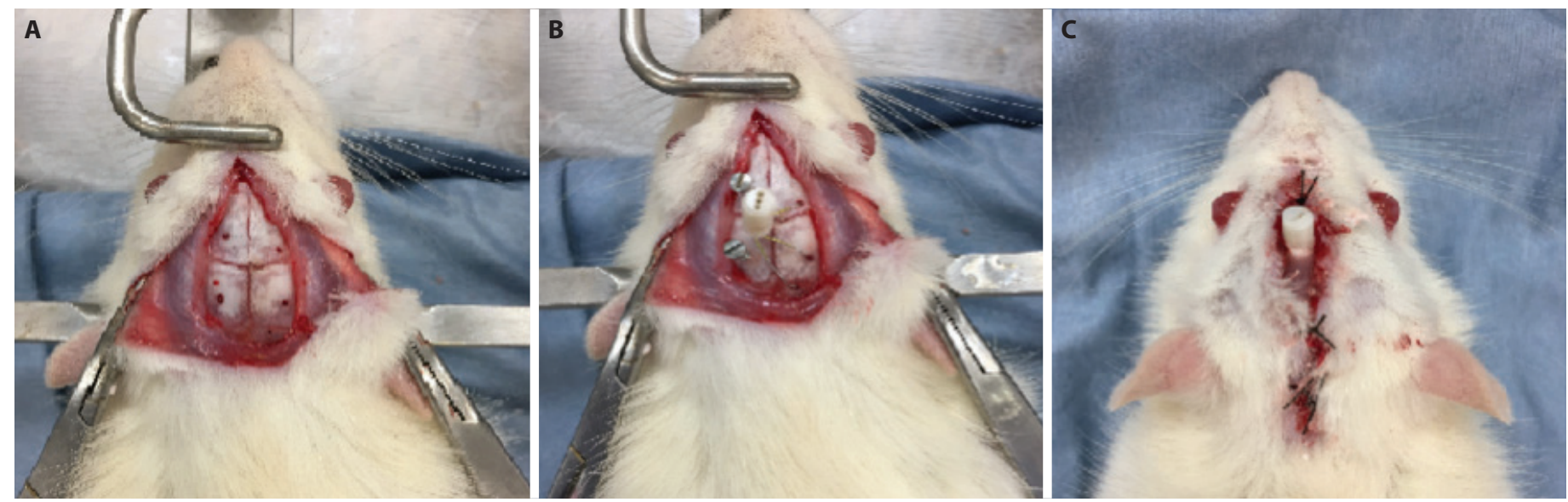

Figure 1. (A) Animals were fixed in the stereotaxic instrument; then micro-drilling of the skull, the electrodes, and stainless screw were inserted on skull. (B) Cold acrylic screws and electrodes were fixed and the scalp was sutured.

activity was video recorded for $5 \mathrm{~min}$ with a video camera. The following parameters were analyzed: the number of squares crossed (locomotor activity) and the duration of grooming episodes. At the start of each test, the apparatus was cleared with $90 \%$ alcohol. Each animal was tested only once. Decreased locomotor activity, a number of rearings and duration of grooming were considered as an indicator of anxiety-like behavior.

\section{Statistical analysis}

All data were analyzed using GraphPad Prism 7 (Software, Inc., La Jolla, CA) and SPSS Version 22.0 (IBM Corp). PairedSamples T-test was applied between two dependent groups in comparison with baseline records of the WAG/Rij groups. All groups were compared by one-way analysis of variance (ANOVA) followed by post hoc test Tukey. Data were expressed as mean \pm standard error of the mean (SEM) for every group's data. For all comparisons, the accepted criterion for the level of significance was set at $p<0.05$.

\section{Results}

The total number and duration of SWDs in ECoG recordings were calculated. The total numbers of SWD's for a 3-h epoch were $129 \pm 19$ and $120 \pm 14$ with a total duration of $878 \pm 22$ and $840 \pm 18 \mathrm{sec}$; in the control and sham groups, respectively. There was no statistically significant change between the control and sham groups ( $p>0.05$ ).

Intraperitoneal administering of $1 \mathrm{mg} / \mathrm{kg}$ duloxetine did not display statistically important change both the number and duration of SWDs. As shown in Figure 3, number and duration of SWDs in ECoG were $129 \pm 19$ and $104 \pm 9$ and $878 \pm 22$ and $792 \pm 55 \mathrm{sec}$ in control group (WAG/Rij rat) and $1 \mathrm{mg} / \mathrm{kg}$ duloxetine group, respectively. Intraperitoneal administering of 5 , 10 and $30 \mathrm{mg} / \mathrm{kg}$ duloxetine significantly decreased both the number and duration of SWDs. As shown in Figure 3, the number and duration of SWDs in ECoG were $129 \pm 19 ; 84 \pm 8 ; 72 \pm 9$ and $878 \pm 22 ; 672 \pm 67 ; 531 \pm 57$ in control group (WAG/Rij rat), at doses of 5,10 and $30 \mathrm{mg} / \mathrm{kg}$ duloxetine group, respectively.

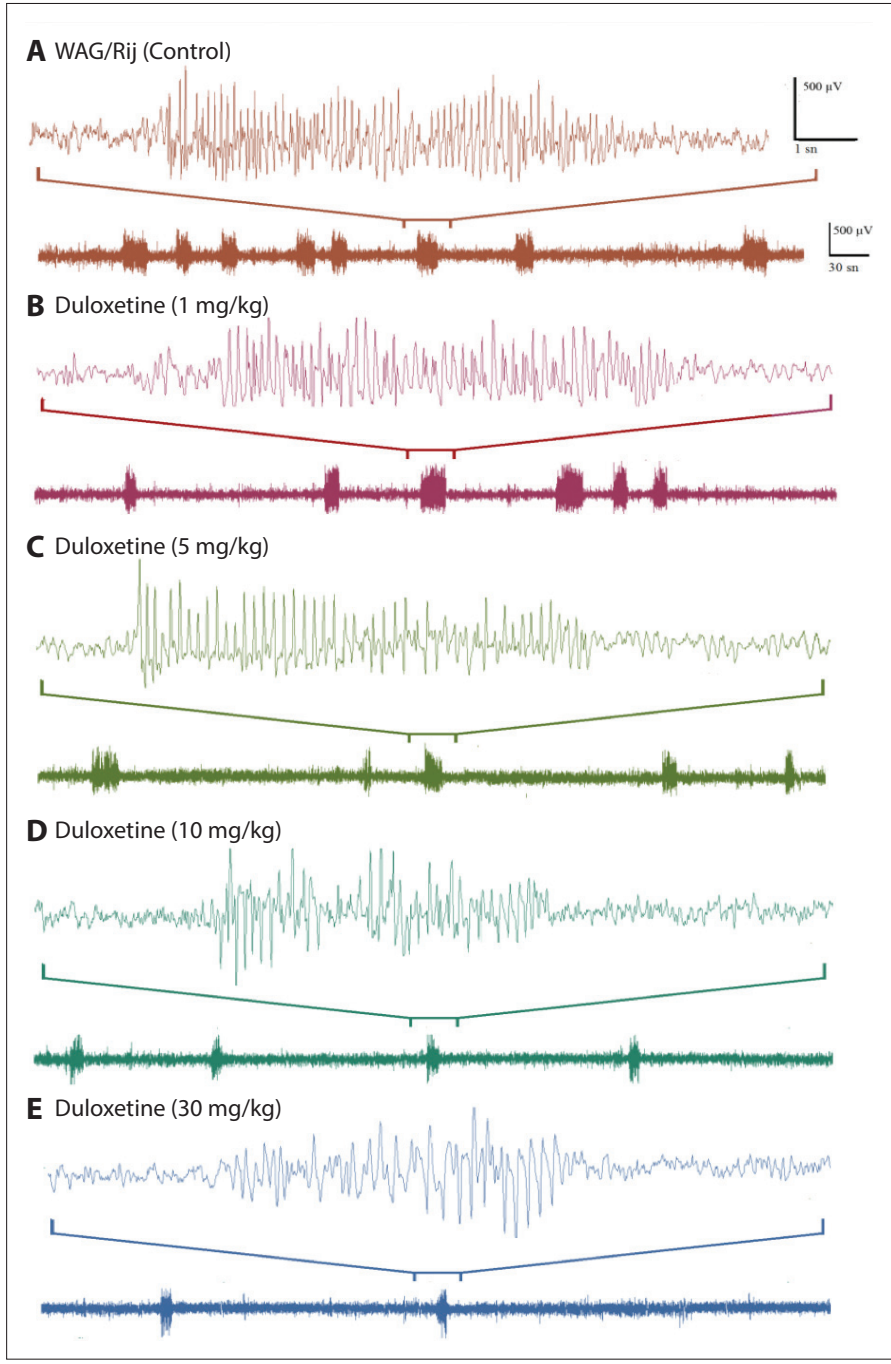

Figure 2. Representative ECoG recordings for all groups with; (A) WAG/Rij (Control); (B) Duloxetine (1 mg/kg), (C) Duloxetine (5 mg/kg), (D) Duloxetine (10 mg/kg), (E) Duloxetine (30 mg/kg). The $1 \mathrm{mg} / \mathrm{kg}$ dose of duloxetine did not show statistically important change both the number and duration of SWDs. 5, 10 and $30 \mathrm{mg} / \mathrm{kg}$ duloxetine significantly reduced both the number and duration of SWDs. 


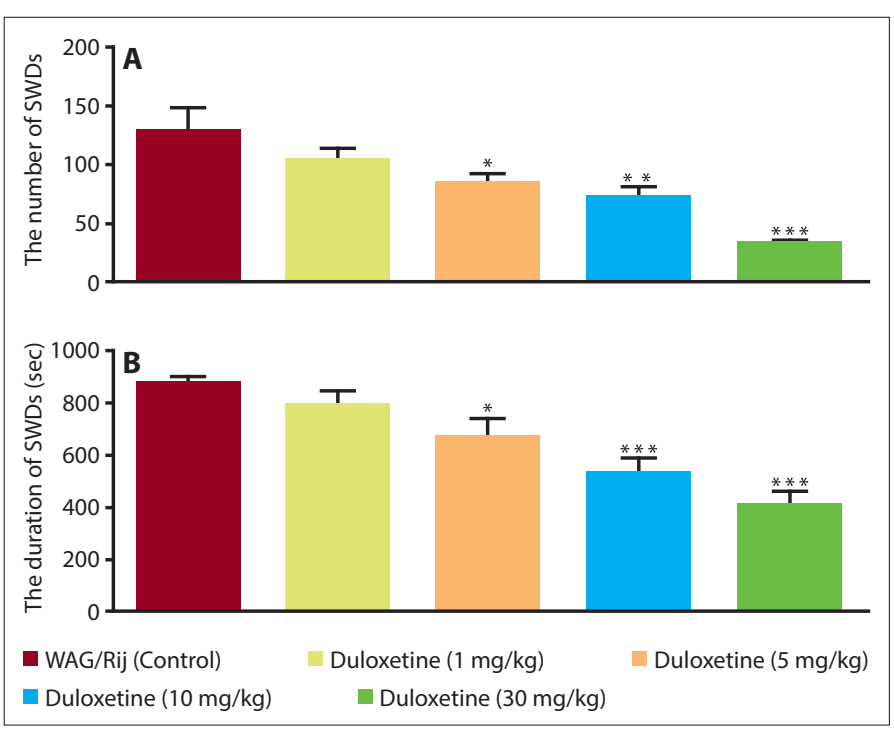

Figure 3. The effects of different doses of duloxetine $(1,5,10$ and 30 $\mathrm{mg} / \mathrm{kg}$ ) on the total number and total duration of SWDs in WAG/Rij rats with genetic absence epilepsy. $1 \mathrm{mg} / \mathrm{kg}$ (i.p.) duloxetine did change the total number and duration of SWDs in WAG/Rij rats compared to the control group ( $p>0.05$ ). The 5, 10 and $30 \mathrm{mg} / \mathrm{kg}$ group duloxetine significantly reduced the total number and duration of SWDs compared to control group $\left({ }^{*} p<0.05 ;{ }^{* *} p<0.01 ;{ }^{* * *} p<0.001\right)$. The total number and duration of SWDs for 3-h epoch was significantly lower in at a dose of $30 \mathrm{mg} / \mathrm{kg}$ duloxetine group compared to the other duloxetine treatment groups.

$30 \mathrm{mg} / \mathrm{kg}$ duloxetine was the most effective dose to decrease both the number and duration of SWDs.

\section{Duloxetine effects in anxiety-like behavior paradigms}

\section{Open Field Test}

Results obtained in the open field test, the number of squares crossed were $45 \pm 2 ; 40 \pm 2$ and with the total duration of grooming $11.8 \pm 1.33$ and $9 \pm 2.30 \mathrm{sec}$; in the control and sham groups, respectively. There was no statistically important change between the control and sham groups ( $p>0.05)$.

Intraperitoneal administering of $1 \mathrm{mg} / \mathrm{kg}$ duloxetine did not show statistically important change both the number of squares crossed and duration of grooming in OFT. As shown in Figure 4 , the number of squares crossed and duration of grooming in OFT were $45 \pm 2$ and $47 \pm 4$ and $11.8 \pm 1.33$ and $10.77 \pm 1.25 \mathrm{sec}$ in control group (WAG/Rij rat) and $1 \mathrm{mg} / \mathrm{kg}$ duloxetine group, respectively. Intraperitoneal administering of 5, 10 and $30 \mathrm{mg} /$ $\mathrm{kg}$ duloxetine significantly decreased the number of squares crossed; however, there was no statistically important change in the duration of grooming in OFT. As shown in Figure 4, number of squares crossed and duration of grooming were $45 \pm 2 ; 62 \pm 4$; $66 \pm 9 ; 72 \pm 8$; and $11.8 \pm 1.33 ; 12.00 \pm 1.73 ; 11.50 \pm 2.10 ; 13.38 \pm 1.57$ in control group (WAG/Rij rat), at doses of 5,10 and $30 \mathrm{mg} / \mathrm{kg}$ duloxetine group, respectively. $30 \mathrm{mg} / \mathrm{kg}$ duloxetine was the most effective dose to moderate anxiolytic properties in OFT.

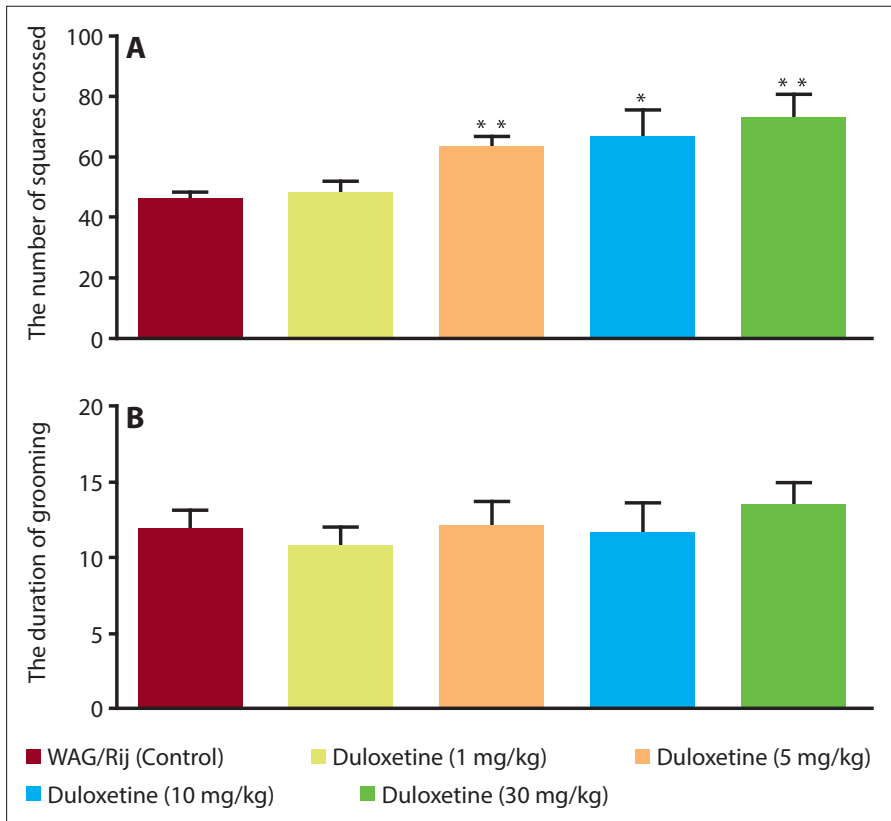

Figure 4. The effects of different doses of duloxetine (1, 5, 10 and 30 $\mathrm{mg} / \mathrm{kg}$ ) on the open field test measures in absence-epileptic WAG/ Rij rat. (A) The number of squares crossed (locomotor activity). (B) The duration of grooming $1 \mathrm{mg} / \mathrm{kg}$ (i.p.) duloxetine did changed the number of squares crossed ( $p>0.05$ ), but 5,10 and $30 \mathrm{mg} / \mathrm{kg}$ duloxetine importantly reduced number of squares crossed when compared to the control group $\left({ }^{*} \mathrm{p}<0.05 ;{ }^{* *} \mathrm{p}<0.01 ;{ }^{* * *} \mathrm{p}<0.001\right)$. All doses of duloxetine did not alter the duration of grooming compared to the control group ( $p>0.05)$.

\section{Discussion}

In this study, the 5, 10 and $30 \mathrm{mg} / \mathrm{kg}$ injection of duloxetine dose-dependently reduced the number and duration of SWDs, also increased the number of squares crossed (locomotor activity) in OFT but did not change the duration of grooming compared to control group. The $1 \mathrm{mg} / \mathrm{kg}$ duloxetine did not significantly alter all parameters in ECoG recording and OFT test. The results of the present study indicate that duloxetine exerts a considerable antiepileptic and anxiolytic-like effect on absence-like seizures in WAG/Rij rats.

Many studies reported that the use of antidepressants in an epileptic patient is controversial because of increase in seizure severity, especially with older generations of drug ${ }^{[5,13]}$ Interestingly, a lot of studies reported that some of the newer antidepressants, such as serotonin and norepinephrine reuptake inhibitors (SNRIs) and selective serotonin reuptake inhibitors (SSRIs) exhibit anticonvulsant effect. ${ }^{[5,13]}$ On the other hand, the possible antiepileptic effect of SNRIs has been scarcely studied. Venlafaxine (SNRI drug), showed anti-epileptic action, whereas high doses of venlafaxine exhibits an increased epileptiform activity, but high doses of venlafaxine $(75 \mathrm{mg} / \mathrm{kg}$ or more) showed a proconvulsant effect. ${ }^{[14-16]}$ The preliminary results in our study have indicated a possible role for the duloxetine in convulsive seizures. In this study, we showed that acute treatment of duloxetine injection of 1,5, 10 and $30 \mathrm{mg} /$ 
kg increased epileptiform activity in penicillin-induced seizure model in the rat. ${ }^{[7]}$ Recently a study reported that seizure-induced respiratory arrest and death was decreased in WT mice with duloxetine treatment in maximal electroshock-induced seizures in adult in mice. ${ }^{[17]}$ Citraro et al. (2015) demonstrated that chronic treatment of duloxetine $(10$ and $30 \mathrm{mg} / \mathrm{kg}$ ) decreased both number and duration of SWDs in adult WAG/Rij rats. $^{[6]}$ In this study, both of the number and duration of SWDs parameters were significantly decreased in 5, 10 and $30 \mathrm{mg} / \mathrm{kg}$ duloxetine treatment groups compared to control. However, both the number and duration of SWDs parameters did not alter in $1 \mathrm{mg} / \mathrm{kg}$ duloxetine treatment. The duloxetine $(30 \mathrm{mg} /$ $\mathrm{kg}$ ) was found the most effective considering both the number and duration of SWD parameters of absence epilepsy.

Zomkowski et al. (2012) demonstrated that a dose range of $1-30 \mathrm{mg} / \mathrm{kg}$ duloxetine did not alter locomotor activity in OFT, but decreased immobility time in the forced swim test. ${ }^{[18]} 30$ $\mathrm{mg} / \mathrm{kg}$ for duloxetine did not significantly change locomotion in the mouse formalin pain model. ${ }^{[19]}$ On the other hand, Grégoire showed that $10 \mathrm{mg} / \mathrm{kg}$ duloxetine decreased anxietylike behavior by increased locomotor activity in a model of neuropathic pain in rats. ${ }^{[20]}$ Also, another study showed that duloxetine $(5 \mathrm{mg} / \mathrm{kg})$ increased center arena activity in OFT. ${ }^{[21]}$ In this study, 5, 10 and $30 \mathrm{mg} / \mathrm{kg}$ duloxetine injection significantly increased locomotor activity, but $1 \mathrm{mg} / \mathrm{kg}$ duloxetine did not alter the number of squares crossed.

A new study demonstrated that $3.0 \mathrm{mg} / \mathrm{kg}$ duloxetine injection significantly elevated the extracellular concentration of dopamine prefrontal cortex and exhibits dopamine 1 receptor (D1)- like effect. ${ }^{[22]}$ Sarkisova et al. reported that D1-like dopamine receptors were very lower in WAG/Rij rats compared with control rats. ${ }^{[23]}$ In their study, they found a significant relationship between increased seizure and anxiety-depressionlike behaviors. In the meantime, they observed an increase in seizure severity and anxiety-like behaviors in rats with low D1 levels. It was shown that hypofunction of the dopaminergic brain system responsible for depression-like behavior in WAG/ Rij rats. ${ }^{[23]}$ Many study demonstrated that dopamine antagonists increased number and duration of SWDs in WAG/Rij rats, while cocaine, apomorphine, and amphetamine (dopamine agonist drug) reduce the number and duration of SWDs. [24-27] When the literature is considered, the dose-dependent antiepileptic and anxiolytic effect of duloxetine treatment may be mediated by the dopamine-enhancing effect.

\section{Conclusion}

Depression is one of the most commonly only psychiatric disorder in people with epilepsy. Antidepressant drugs are the third class of drugs commonly used by patients with epilepsy. [28] The same antidepressant drug has different effects on different types of epilepsy. The present study was the first to investigate the effect of duloxetine on drug dose effect and anxiety-like behaviors in absence epilepsy in WAG/Rij rats. Although it is an animal study, it may be useful to use in patients with abscence epilepsy.
Conflict of interest: There are no relevant conflicts of interest to disclose.

\section{References}

1. Zupec-Kania BA, Spellman E. An overview of the ketogenic diet for pediatric epilepsy. Nutr Clin Pract. 2009;23(6):589-596.

2. Barry JJ, Ettinger AB, Friel $P$, et al. Consensus statement: the evaluation and treatment of people with epilepsy and affective disorders. Epilepsy Behav 2008;13(Suppl. 1): S1-29.

3. Tellez-Zenteno JF, Patten SB, Jetté N, et al. Psychiatric comorbidity in epilepsy: a population-based analysis. Epilepsia 2007;48:23362344.

4. Sillanpää M, Schmidt D. Natural history of treated childhoodonset epilepsy: prospective, long-term population-based study. Brain 2006;129(Pt 3):617-624.

5. Cardamone L, Salzberg MR, O'brien TJ, Jones NC. Antidepressant therapy in epilepsy: can treating the comorbidities affect the underlying disorder?. British J Pharmacol 2013;168(7):1531-1554.

6. Citraro R, Leo A, De Fazio P, et al. Antidepressants but not antipsychotics have antiepileptogenic effects with limited effects on comorbid depressive-like behavior in the WAG/Rij rat model of absence epilepsy. Br J Pharmacol 2015;172(12):3177-3188.

7. Esen $M$, Aygun $H$. The effect of duloxetine on penicillin-induced epileptiform activity in rats. Neurological Res 2019;41(4):298-305.

8. Wong DT, Bymaster FP, Mayle DA, et al. LY248686, a new inhibitor of serotonin and norepinephrine uptake. Neuropsychopharmacol 1993;8(1):23-33.

9. van Luijtelaar G, Zobeiri M. Progress and outlooks in a genetic absence epilepsy model (WAG/Rij). Curr Med Chem 2014;21:704721.

10. Sarkisova K, van Luijtelaar G. (2011) The WAG/Rij strain: a genetic animal model of absence epilepsy with comorbidity of depression. Prog Neuropsychopharmacol Biol Psychiatry In press.

11. Aygun H, Aydin D, Inanir S, Ekici F, Ayyildiz M, Agar E. The effects of agomelatine and melatonin on ECoG activity of absence epilepsy model in WAG/Rij rats. Turkish J Biology 2015;39: 904-910.

12. Aygun H, Ayyildiz M, Agar E. Swimming exercise decreases the absence-like epileptic activity in WAG/Rij rats. Behav Brain Res 2019;363:145-148.

13. Jobe PC, Browning RA. The serotonergic and noradrenergic effects of antidepressant drugs are anticonvulsant, not proconvulsant. Epilepsy Behav 2005;7(4):602e619

14. Santos Jr JG, do Monte FH, Russi M, et al. Proconvulsant effects of high doses of venlafaxine in pentylenetetrazole-convulsive rats. Braz J Med Biol Res 2002;35(4):469-472.

15. Borowicz KK, Gołyska D, Luszczki JJ, et al. Effect of acutely and chronically administered venlafaxine on the anticonvulsant action of classical antiepileptic drugs in the mouse maximal electroshock model. European J Pharmacol 2011;670(1):114-120

16. Ahern TH, Javors MA, Eagles DA, et al. The effects of chronic norepinephrine transporter inactivation on seizure susceptibility in mice. Neuropsychopharmacol 2006;31:730-738.

17. Kruse SW, Dayton KG, Purnell BS, et al. Effect of monoamine reuptake inhibition and a1 blockade on respiratory arrest and death following electroshock-induced seizures in mice. Epilepsia 2019;60(3):495-507.

18. Zomkowski AD, Engel D, Cunha MP, Gabilan NH, Rodrigues ALS. The role of the NMDA receptors and L-arginine-nitric oxide-cyclic guanosine monophosphate pathway in the antidepressant-like 
effect of duloxetine in the forced swimming test. Pharmacol Biochem Behav 2012;103(2):408-417.

19. Sun YH, Dong YL, Wang YT, et al. Synergistic analgesia of duloxetine and celecoxib in the mouse formalin test: a combination analysis. PloS one 2013;8(10):e76603.

20. Grégoire S, Michaud V, Chapuy E, et al. (2012). Study of emotional and cognitive impairments in mononeuropathic rats: effect of duloxetine and gabapentin. Pain 2012;153(8):1657-1663.

21. Cui R, Wang L, Liu L, Ruan H, Li X. Effects of noradrenergic and serotonergic systems on risk-based decision-making and center arena activity in open field in rats. Eur J Pharmacol 2018;841:57-66.

22. Sasamori H, Ohmura Y, Yoshida T, Yoshioka M. Noradrenaline reuptake inhibition increases control of impulsive action by activating D1-like receptors in the infralimbic cortex. Eur J Pharmacol 2019;844:17-25.

23. Sarkisova K, Kulikov MA, Kudrin VS, et al. Neurochemical mechanisms of depression-like behavior in WAG/Rij rats. Zh Vyssh Nerv Deiat Im I P Pavlova 2013;63(3):303-315.
24. Midzyanovskaya IS, Kuznetsova GD, Coenen AM, et al. Electrophysiological and pharmacological characteristics of two types of spike-wave discharges in WAG/Rij rats. Brain Res 2001;91:62-70.

25. Sarkisova KYu, Midzyanovskaya IS, Kuznetsova GD, van Luijtelaar $\mathrm{G}$. The involvement of the brain dopaminergic system in the pathogenesis of absence seizures and depressive-like behavioral alterations in WAG/Rij rats. FENS Abstr 2006;3:A024-29.

26. Sarkisova KYu, Kulikov MA, Midzyanovskaya IS, Folomkina AA. Dopamine-dependent character of depressive-like behavior in WAG/Rij rats with genetic absence epilepsy. Zh Vissh Nervn Dejat 2007;57:91-102.

27. Depaulis A, van Luijtelaar G. Genetic models of absence epilepsy in the rat. In: Pitkanen A, Schwartzkroin P, Moshe S, editors. Animal models of seizures and epilepsy. San Diego: Elsevier Inc; 2006. p. 233-248.

28. Wilner AN, Sharma BK, Thompson A, et al. Diagnoses, procedures, drug utilization, comorbidities, and cost of health care for people with epilepsy in 2012. Epilepsy \& Behav. 2014;41:83e90. 